\title{
Pemasaran empatik sebagai strategi komunikasi merek di masa pandemi Covid-19
}

\author{
Yuliani Dewi Risanti ${ }^{1}$, Renata Anisa ${ }^{2}$, Puji Prihandini ${ }^{3}$ \\ 1,2,3 Universitas Padjadjaran, Bandung, Indonesia
}

\begin{abstract}
ABSTRAK
Pandemi Covid-19 turut mengubah bagaimana merek melakukan komunikasi dengan konsumennya. Di saat daya beli konsumen menurun, konsumen ditantang untuk mengevaluasi kembali apa yang menjadi prioritas dalam melakukan pembelian. Kondisi ini menjadikan persaingan antar merek semakin kompetitif sehingga komunikasi merek sangat penting dilakukan agar merek tetap melekat dalam ingatan konsumen. Dalam penelitian ini bertujuan untuk mengkaji bagaimana merek global melakukan komunikasi merek dalam aspek isi pesan dan media yang digunakan. Pemilihan merek global dalam penelitian ini berdasarkan pencarian kata kunci komunikasi merek di masa pandemi. Penelitian ini menggunakan metode penelitian kualitatif deskriptif, mengungkapkan keadaan obyek penelitian pada saat ini berdasarkan fakta. Teknik analisis data dalam penelitian dilakukan secara interaktif yaitu reduksi data, penyajian data dan penarikan kesimpulan. Hasil penelitian menunjukan merek global yang menjadi objek dalam kajian ini melakukan strategi komunikasi merek berbasis empati. Pemasaran empati atau pemasaran berbasis empati merupakan teknik pemasaran yang digunakan dengan mencoba memahami apa yang dialami, menunjukan upaya membantu serta pembentukan ikatan emosional dengan konsumen melalui penyampaian pesan yang relevan. Dalam aspek isi pesan yang diangkat oleh merek adalah dukungan terhadap upaya pencegahan penularan virus melalui tagline dan tagar di akun media sosial resmi perusahaan, penyaluran donasi serta penghargaan kepada orang yang berperan dalam membantu orang banyak melewati krisis Covid-19. Sedangkan media yang digunakan yaitu website dan akun media sosial resmi perusahaan serta akun media sosial pengikut merek-merek tersebut. Komunikasi merek dengan berbasis empati relevan dengan kondisi krisis pandemi Covid-19 dimana konsumen saat ini lebih mengutamakan kesehatan serta kesejahteraan.
\end{abstract}

Kata-kata kunci: Komunikasi merek; strategi komunikasi; pemasaran empatik; merek; Covid-19

\section{Empathetic marketing as brand communication strategy in pandemic Covid-19}

\section{ABSTRACT}

The Covid-19 pandemic has also changed how brands communicate with their consumers. When buying power of consumers decreases, consumers are challenged to re-evaluate what is the priority in making purchases. This condition makes competition between brands more competitive therefore brand communication is very important to do so that brands remain to be remembered by consumers. In this study, the aim of this research is to examine how global brands communicate brand in the aspects of message content and the media used. The selection of global brands in this study is based on keyword searches for brand communication during a pandemic. This study uses descriptive qualitative research methods, revealing the current state of the research object based on facts. The data analysis technique in this research was carried out interactively, namely data reduction, data presentation and drawing conclusions. The results showed that the global brands that were the object of this study carried out an empathy-based brand communication strategy. Empathy marketing or empathy-based marketing is a marketing technique used by trying to understand what is being experienced, showing efforts to help and forming emotional bonds with consumers through the delivery of relevant messages. In the aspect of the message content raised by the brand, it is support for efforts to prevent virus transmission through taglines and hashtags on the company's official social media accounts, channeling donations and awards to people who play a role in helping people through the Covid-19 crisis. Meanwhile, the media used are the company's official website and social media accounts as well as the brand's followers'social media accounts. Empathy-based brand communication is relevant to the conditions of the Covid-19 pandemic crisis where consumers currently prioritize health and well-being.

Keywords: Brand communication; communication strategy; empathetic marketing; brand; Covid-19

Korespondensi: Yuliani Dewi Risanti, S.I.Kom, M.B.A. Universitas Padjadjaran. Jl. Raya BandungSumedang Km 21 Jatinangor 45363. Email: yuliani@unpad.ac.id 


\section{PENDAHULUAN}

Covid-19 telah mengubah cara merek melakukan komunikasi pada konsumennya. Merek merupakan penghubung antara konsumen dengan perusahaan, dan konsumen dapat mengembangkan kepercayaan dan loyalitas terhadap merek (Kotler \& Keller, 2012). Merek bukan lagi sekedar simbol atau nama produk namun lebih dari itu merek merupakan representasi dari janji yang diberikan produsen kepada konsumennya (Kotler \& Armstrong, 2005). Menurut David A. Aaker keberadaan merek sangat penting sebagai pertanda yang memudahkan konsumen dalam mengenali sebuah produk tertentu. Lebih dari itu, keberadaan merek juga akan membantu melindungi sebuah produk dari adanya persaingan ataupun juga beberapa produk yang memiliki ciri tampilan yang identik (Aaker, 2012). Merek dapat membedakan antara satu produk dengan produk yang lainnya. Melalui merek, konsumen akan dengan mudah mengenali produk yang akan dibeli. Merek merupakan asset berharga yang dimiliki oleh perusahaan yang dapat memberikan keuntungan jangka panjang bila dikelola dengan baik (Aaker, 2014).

Oleh karena itu, merek menjadi bagian yang sangat penting dalam pemasaran. Pengelolaan merek yang tepat akan mendukung penjualan produk. Tujuan mendasar dari pembangunan merek adalah melalui tingkatan membangun kesadaran akan keberadaan merek, membangun asosiasi merek dan menciptakan kesetiaan konsumen terhadap merek (Aaker, 2014).

Sebagai bagian dari pengelolaan merek, komunikasi merek memegang peranan penting agar perusahaan dapat bertahan dan berkembang (Gary et al., 2001). Komunikasi merek merupakan proses penyampaian pesan dari perusahaan kepada konsumen melalui penggunaan media tertentu yang menghasilkan evaluasi keseluruhan dari konsumen mengenai merek yang dapat mempengaruhi perilaku pembelian dan dapat menimbulkan kepercayaan serta kesetiaan terhadap merek (Keller, 2013). Penyampaian nilai perusahaan melalui komunikasi merek kepada pasar sasaran dan mendapatkan umpan balik yang positif dari khalayak seperti karyawan, pelanggan dan mitra merupakan langkah yang penting untuk dapat memenangkan persaingan (Keller, 2013; Kotler, 2020). Dari semua langkah yang harus diikuti dalam komunikasi merek, membangun dan menyampaikan misi, visi dan tujuan secara benar merupakan hal yang sangat penting dan seharusnya menjadi pertimbangan serius perusahaan dalam pengelolaan komunikasi merek (Ingenhoff \& Fuhrer, 2010).

Misi, visi dan tujuan merupakan elemen inti tak berwujud dari sebuah merek dan 
penyampaian hal ini memegang peranan penting dalam pembentukan citra dan reputasi kompetitif perusahaan secara kuat sehingga dapat membangun hubungan dan keterikatan yang baik dengan konsumen dan hal tersebut tercermin pada isi pesan yang disampaikan oleh merek (Miao, 2021). Pengelolaan komunikasi merek menjadi sangat penting agar pesan dari merek dapat diterima dengan baik oleh konsumen. Mulai dari menetapkan tujuan komunikasi merek, melakukan analisis khalayak, pemilihan penyampai pesan, pengemasan pesan, pemilihan media yang digunakan dalam penyampaian pesan sehingga dapat sesuai dengan khalayak sasaran hingga melakukan evaluasi.

Pada saat krisis, perusahaan biasanya mengurangi pengeluaran pada kegiatan komunikasi atau periklanan. Namun sebenarnya saat ini merupakan waktu terbaik untuk memodifikasi strategi komunikasi agar perusahaan dapat membangun ketahanan merek dikalangan pelanggan (Kotler, 2020). Perusahaan yang tetap menjaga komunikasi dengan pelanggan dapat mengungguli dan memenangkan 'share of voice' yang lebih besar bila competitor kurang berkomunikasi atau tidak sama sekali selama periode yang sama (Hoekstra et al, 2020).

Penyampaian isi pesan serta pemilihan media komunikasi yang digunakan oleh perusahaan harus relevan dengan kondisi saat ini. Seperti diketahui, virus Covid-19 pertama kali teridentifikasi pada bulan Desember 2019 di kota Wuhan, Ibu Kota Provinsi Hubei di China sampai saat ini masih melanda banyak negara di berbagai belahan dunia sehingga World Health Organization (WHO) menyatakan virus Covid-19 sebagai pandemi yakni epidemi yang menyebar ke berbagai negara atau dunia. Kondisi dunia saat ini mengalami tantangan yang sangat berat dimana krisis Covid-19 melanda dan berdampak pada semua aspek kehidupan. Walaupun upaya percepatan pembuatan dan distribusi vaksin telah banyak dilakukan oleh beberapa negara, namun dampak dari penyebaran virus ini bukan hanya pada aspek kesehatan namun juga pada aspek ekonomi dimana saat ini telah mengakibatkan banyak negara mengalami resesi. Sebagian besar perusahaan kesulitan untuk menjual produknya pada konsumen bahkan tidak sedikit yang gulung tikar.

Periode deprivasi dan kecemasan ini akan mengantarkan sikap dan perilaku konsumen baru sebagai akibat dari daya beli yang menurun, konsumsi produk diutamakan pada hal yang sangat penting (Kotler, 2020). Masyarakat cenderung akan menjadi sangat selektif dalam melakukan pembelian produk. Konsumen benar-benar memperhatikan secara lebih seksama pada produk yang akan dikonsumsi. 
Dalam lingkungan persaingan global yang semakin kompetitif dengan banyaknya produk yang dihomogenisasi, dalam hal fungsi dan material, menghadapi tekanan penjualan yang semakin meningkat (Ingenhoff \& Fuhrer, 2010). Sebagai konsekuensinya, perusahaan harus mengadopsi pengelolaan merek secara serius karena merek merupakan hal yang penting di mata konsumen.

Berdasarkan studi dari Forrester Study menyebutkan bahwa sebanyak 52 persen dari penduduk usia matang di US memilih untuk membeli produk dari perusahaan yang menunjukan bagaimana mereka melindungi konsumen dari ancaman Virus Covid-19, pada bagaimana merek-merek yang ada dan sering digunakan tersebut bereaksi terhadap pandemi.
Komunikasi merek yang dilakukan oleh perusahaan bukan lagi berupa manfaat produk. Lebih jauh dari itu, konsumen mengharapkan bahwa merek dapat memberikan mereka rasa aman sehingga dapat menimbulkan kepercayaan terhadap merek tersebut.

Dalam studi yang dilakukan oleh Statista. com mengenai pandangan konsumen pada komunikasi merek yang dilakukan selama masa pandemi Covid-19 di beberapa negara di seluruh dunia. Hasilnya menunjukkan bahwa presentase mendengar tentang komunikasi merek yang digunakan mengenai tanggapan terhadap adanya pandemi membuat konsumen nyaman dan yakin lebih tinggi dibandingkan dengan bahwa semua komunikasi merek mengenai virus hanya menambah kecemasan dan kekhawatiran.

\section{Consumer views on brand communication during 1 worldwide as of March 2020, by country}

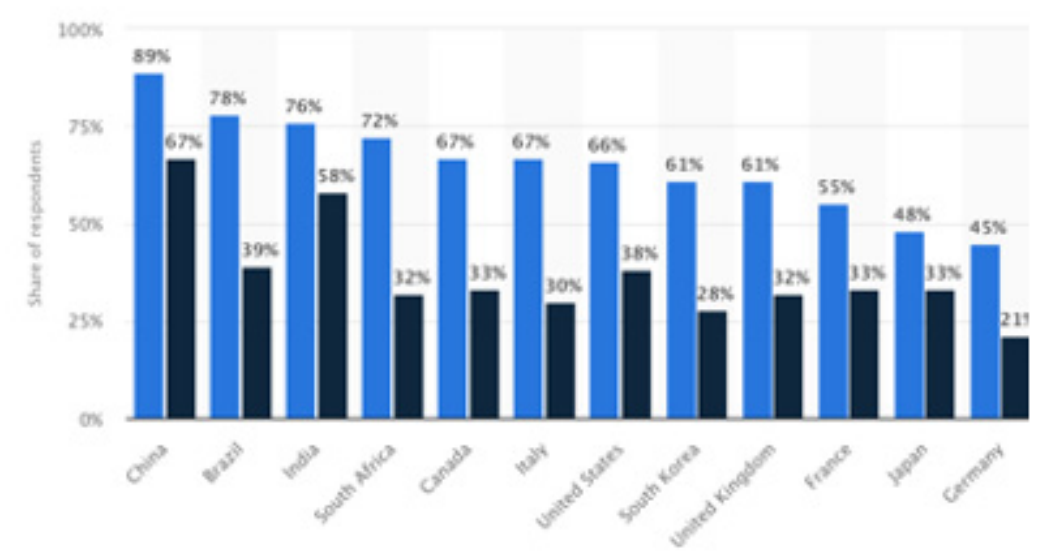

Hearing from brands I use about what they are doing to respond to the pandemic is comfortin...

- All of the communications I am getting from brands about the virus are just adding to my anxi... 
Studi ini menunjukkan bahwa secara global komunikasi merek yang dilakukan dapat memberikan konsumen rasa nyaman dan yakin terhadap merek yang digunakan bukan malah menimbulkan kecemasan dan kekhawatiran. Rasa nyaman dan yakin dapat timbul manakala konsumen percaya pada merek tersebut. Dalam hal ini, merek harus selalu relevan dengan kondisi yang dialami oleh konsumen sehingga konsumen dapat selalu merasakan keberadaan merek tersebut.

Konsep pemasaran berbasis empati mulai banyak digunakan oleh perusahaan pada kondisi krisis seperti saat ini. Empati sendiri merupakan respon emosional (afeksi) hasil dari pengaruh karakter dan keadaan, yang dapat mengarah pada perilaku dengan penekanan lebih pada bagaimana perasaan penerima bukan pada apa yang kita inginkan (Cameron, C. D., et al., 2019). Konsep ini digunakan dalam pemasaran untuk menggambarkan bagaimana perusahaan tersebut ikut memikirkan apa yang dirasakan serta dialami oleh konsumennya lebih jauh lagi bagaimana perusahaan tersebut dapat membuat konsumennya merasa lebih baik. Salah satu alat yang digunakan untuk membuat analisis mengenai empati dalam pemasaran ini adalah dengan menggunakan Empathy Map dari Dave Gray (Coppola, 2017). Kegunaannya adalah untuk mengenal target pasar sasaran dengan menyeleraskan antara strategi bisnis serta value proposition dengan kebutuhan, keinginan, tujuan serta perasaan konsumen.

Sedangkan dalam pemilihan media komunikasi yang digunakan dalam menjalankan komunikasi merek juga terpengaruh dengan adanya anjuran untuk tetap tinggal di rumah yang menyebabkan meningkatnya pengguna internet. Berdasarkan data yang dirilis oleh We Are Social dan Hootsuite.com dalam Digital 2021 report for Indonesia, saat ini pengguna internet di Indonesia yaitu sebanyak 202.6 juta pengguna atau $73.7 \%$ dari total jumlah penduduk di Indonesia (Social, 2021). Kehadiran media baru telah mengubah bagaimana informasi disajikan dan dibagikan. Penyajian dan penyebaran informasi menjadi lebih cepat dan bersifat real time. Popularitas Google sebagai mesin pencarian utama yang banyak digunakan oleh masyarakat Indonesia serta media sosial Instagram dan YouTube terus meningkat yakni sebanyak 170 juta pengguna aktif media sosial atau $61.8 \%$ dari jumlah total populasi Indonesia dimana durasi yang digunakan untuk mengakses media sosial yaitu selama 3 jam 14 menit dimana hampir 100\% menggunakan mobile phone sebagai alat yang digunakan dalam mengakses sosial media (Social, 2021). Dengan kondisi seperti itu, perusahaan pun harus mulai melakukan komunikasi secara intensif melalu kanal-kanal seperti website resmi perusahaan atau sosial media. Kanal sosial media menjadi 
saluran yang semakin penting bagi merek untuk berkomunikasi dengan target khalayak sasaran (Murdough, 2009). Sejak awal kemunculannya, kanal sosial media telah menciptakan cara baru bagi individu, merek maupun perusahaan untuk berkomunikasi, berkolaborasi dan berbagi informasi dengan pihak lain yang memiliki kesamaan ketertarikan (Kusumasondjadja, 2018). Sebagai contoh, sosial media semakin banyak digunakan oleh para pemasar sebagai alat komunikasi dengan konsumen melalui pembagian informasi produk, berinteraksi dengan konsumen, merespon pertanyaan atau keluhan dan kegiatan pemasaran lainnya.

Dalam kondisi saat ini, peralihan ke konten digital dilakukan dengan pendekatan personal dan fokus pada pesan yang menyatakan dukungan pada upaya pencegahan penyebaran virus Covid-19. Hal tersebut dapat membangun keterikatan dengan konsumen yang pada akhirnya dapat mempengaruhi persepsi khalayak mengenai merek tersebut (Hoekstra, 2020). Menunjukan empati untuk situasi yang dialami konsumen saat ini dan pada lingkungan yang lebih luas lagi akan membangun itikad baik dari konsumen. Melakukan analisa bagaimana perjalanan konsumen dalam pembelian produk dan menemukan cara agar konsumen dapat terhindar dari kontak langsung dapat mengurangi rasa khawatir akan resiko penularan dan mendorong terjadi pembelian produk lebih besar (Steimer, 2020).

Dalam studi ini akan mengkaji bagaimana implementasi strategi komunikasi merek yang dilakukan oleh merek-merek global pada saat pandemi Covid-19. Kajian yang akan dilakukan meliputi isi pesan dan penggunaan media yang dipilih dalam menyampaikan pesan komunikasi merek untuk dapat mempertahankan reputasi merek serta membangun keterikatan dengan konsumennya. Penelitian ini dapat menjadi studi awal dalam melakukan kajian pada dampak komunikasi merek yang dilakukan terhadap perilaku konsumen sebagai dasar pengambilan keputusan dalam melakukan perencanaan strategi bauran pemasaran serta sebagai kajian literatur yang dapat menjadi referensi bagi pemasar di Indonesia mengenai bagaimana strategi komunikasi merek dilakukan selama pandemi Covid-19.

\section{METODE PENELITIAN}

Penelitian ini menggunakan metode penelitian kualitatif deskriptif, yaitu mengungkapkan keadaan obyek penelitian pada saat penelitian berlangsung berdasarkan fakta (Sugiyono, 2016). Teknik analisis data dalam penelitian dilakukan secara interaktif yaitu reduksi data, penyajian data dan penarikan kesimpulan (Moleong, 2017). Teknik pengumpulan data melalui observasi dan dokumentasi serta studi literatur. 
Pada penelitian ini juga meninjau dan melakukan kajian secara kritis dari pengetahuan, ide ataupun temuan yang ada pada literatur akademik untuk merumuskan kontribusi teoritis dan metodologisnya untuk topik tertentu (Zed, 2004). Pendekatan studi literatur secara mendalam dan kritis terkiat sebuah konsep juga telah dilakukan oleh penulis dalam jurnal ini yaitu pada artikel Strategi aktivisme digital di Indonesia: aksesibilitas, visibilitas, popularitas, dan ekosistem aktivisme (Rahmawan, et al., 2020).

Dalam penelitian ini yang akan dibahas adalah bagaimana strategi komunikasi merek yang dilakukan oleh merek-merek global di masa pandemi Covid-19. Penelitian ini mengkaji bagaimana isi pesan yang disampaikan serta pemilihan media yang digunakan oleh merekmerek tersebut dalam menyampaikan pesan pada konsumennya.

Beberapa pertimbangan penggunaan pendekatan kualitatif deskriptif dalam penelitian ini adalah sebagai kajian awal yang merupakan tahap pendahuluan dalam memahami lebih jauh bagaimana dampak Covid-19 pada komunikasi merek dan lebih jauh lagi apakah berpengaruh terhadap persepsi ataupun keputusan konsumen dalam penggunaan produk tersebut yang tentunya memerlukan penelitian lebih lanjut. Pertimbangan lainnya adalah sumber penelitian dari masa pandemi masih terbatas sehingga kajian ini diperlukan untuk dapat menjadi pleminary research pada topik komunikasi merek di saat pandemi serta bagaimana pengaruhnya pada konsumen. Objek penelitian ini adalah merek global dari berbagai kategori yaitu activewear yaitu Nike dan Adidas, fast fashion Uniqlo serta majalah fashion Vouge UK yang secara konsisten melakukan komunikasi merek selama pandemi. Pemilihan merek yang menjadi objek dalam penelitian ini adalah merek yang sering muncul melalui kata kunci 'brand communication during pandemic', 'brand communication in the Era of Covid-19', 'How brand should communicate during pandemic' Merek-merek global tersebut menjadi contoh kasus pada banyak tulisan di kanal berita online mengenai bagaimana komunikasi merek dilakukan selama pandemi. serta mendapatkan tanggapan cukup siginifikan pada sosial media melalui penggunaan hashtag pada unggahan konten dari pengikut pada merek-merek global tersebut Adapun untuk mengetahui dampak dari komunikasi merek tersebut pada keputusan pembelian konsumen terhadap merek diperlukan penelitian lebih lanjut.

\section{HASIL DAN PEMBAHASAN}

Ketidapastian masa pandemi mengakibatkan para pelaku usaha harus mengatur ulang strategi pemasaran produknya. Mulai dari proses produksi, distribusi sampai 
dengan bagaimana berkomunikasi dengan pelanggannya. Pada kondisi saat ini dimana transaksi bisnis mengalami perubahan, konsumen sebagai mitra langsung pun berubah. Kondisi krisis memaksa konsumen untuk lebih berhati-hati dalam membelanjakan uangnya dan akan melakukan evaluasi terhadap pembelian produk hanya benar-benar pada yang esensial (Kotler, 2020). Konsumen menjadi lebih berfokus pada nilai-nilai apa yang dimiliki oleh perusahaan (Santoso, 2020). Nilai yang dimiliki oleh perusahaan merupakan elemen intangible dari merek produk (Miao, 2021).

Merek merupakan hal yang sangat penting bagi pasar konsumen. Merek merupakan penghubung antara konsumen dan perusahaan, dan konsumen dapat mengembangkan kepercayaan dan kesetiaan pada merek (Zehir, Cemal., et al, 2011). Merek adalah simbol, tanda, rancangan ataupun kombinasi dari tidak hal tersebut yang ditujukan sebagai identitas dari beberapa penjual untuk kemudian dijadikan sebagai pembeda dengan produk lain yang sejenis atau pesaing yang ada di pasaran (Kotler \& Keller, 2012).

Merek yang baik adalah merek yang dapat bertindak sebagai teman, yang hadir untuk konsumennya pada saat kondisi baik dan buruk. Kualitas seperti ini yang membuat konsumen mempercayai merek seperti mereka mempercayai seorang teman.
Dalam kondisi seperti saat ini, merek-merek harus mengesampingkan agenda penjualan semata dan bersiap untuk melakukan sedikit pengorbanan dengan cara lebih menunjukan rasa kepedulian dan pengorbanan yang tinggi terhadap konsumennya (Anand, 2020).

Konsep pemasaran empati mulai banyak digunakan oleh pemasar dalam memasarkan produknya terutama pada kondisi krisis agar tetap relevan dengan konsumennya. Menurut ilmu psikologi, empati adalah pengalaman memahami kondisi orang lain dari sudut pandang orang tersebut, menempatkan diri pada posisi orang tersebut dan merasakan apa yang dirasakan (Cuff, B., et al, 2012).

Ketika perusahaan berempati pada konsumen, perusahaan tersebut cenderung akan mulai menghasilkan layanan dan produk yang lebih baik sehingga meningkatkan persepsi konsumen mengenai merek dan layanan perusahaan tersebut. Dengan mengimplementasikan empati dalam konsep pemasaran, memungkinkan produsen untuk dapat memahami apa yang menjadi kebutuhan pelanggan, anggota keluarga dan bahkan teman. Tidak perlu membuat produk yang hanya sekedar menyenangkan untuk dimiliki namun memiliki kesempatan untuk menjual produk yang harus dimiliki sehingga memiliki kesempatan unggul lebih besar (Coppola, 2017). Tujuan dari pemasaran berbasis empati bukan hanya untuk 

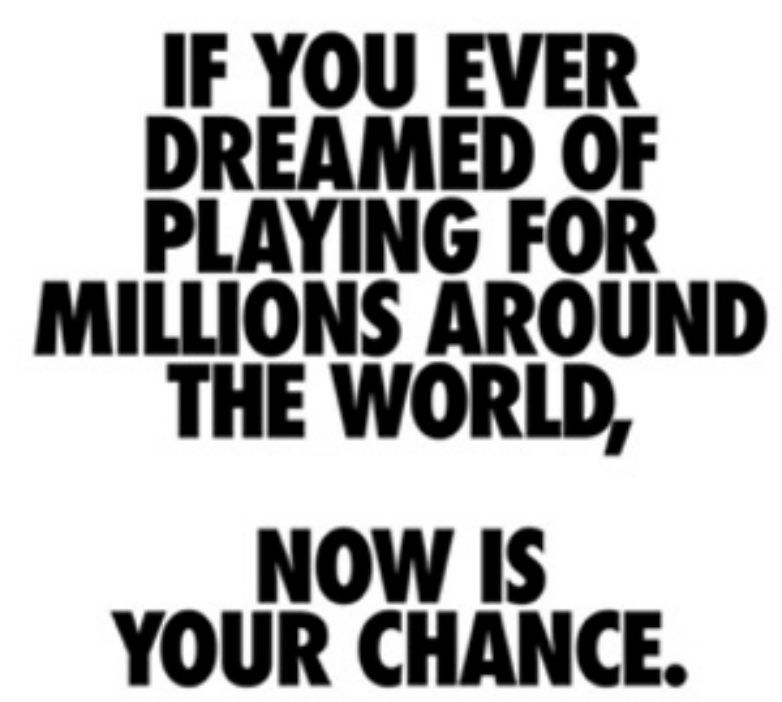

Play inside, play for the world.

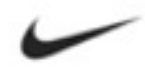

Sumber: Akun Instragam resmi Nike@nike 2020

Gambar 2 Kampanye Nike selama pandemi

mencari tahu produk apa yang benar-benar dibutuhkan oleh konsumen namun juga untuk dapat selalu relevan dengan konsumen sehingga dapat meningkatkan kepercayaan konsumen pada merek. Komunikasi merek berbasis empati yaitu bagaimana merek tersebut berusaha untuk memahami dan bahkan menempatkan dirinya pada konsisi saat ini. Isi pesan yang disampaikan oleh merek-merek tersebut sebisa mungkin relevan dengan situasi yang dihadapi oleh konsumen.

Adanya pandemi virus Corona (Covid-19) yang melanda sebagian besar negara diseluruh dunia, telah mengubah bagaimana cara manusia menjalani kehidupan. Sebagai upaya pencegahan virus Covid-19, beberapa negara memberlakukan lockdown ataupun pembatasan sosial berskala besar. Hampir semua aktifitas yang biasanya dilakukan diluar rumah mulai dari bekerja, belajar, berbelanja, berolahraga dilakukan dari rumah. Kondisi tersebut membuat beberapa merek global melakukan komunikasi merek dengan mengangkat isu tersebut sebagai pesan utamanya.

Sebagai contohkampanye "PlayInside, Play for the World" seperti yang dikomunikasikan oleh brand global perlengkapan olahraga Nike. Dalam akun sosial media resminya, Nike menyampaikan pesan anjuran untuk melakukan aktivitas berolahraga di rumah, dengan demikian 
kita berkesempatan untuk ambil bagian menjadi pemain dunia.

Saat ini kategori industri perlengkapan olahraga mengalami penurunan penjualan yang cukup signifikan dengan adanya kebijakan lockdown di banyak negara dimana industri ini sangat bergantung pada aktivitas olahraga yang biasanya dilakukan diluar rumah. Adanya kebijakan lockdown tentunya menyebabkan berbagai perhelatan olahraga juga dihentikan untuk kurun waktu yang tidak dapat diprediksi tentunya turut berdampak pada penurunan penjualan produk. Seperti pada gambar 3 yang menunjukkan data pendapatan merek Nike dari penjualan produknya di seluruh dunia dimana dari tahun 2019 ke 2020 mengalami penurunan kurang dari 10\% dimana pada tahun-tahun sebelumnya rata-rata mengalami kenaikan.

Merek activewear global lainnya yang juga melakukan komunikasi merek selama pandemi yaitu Adidas. Lain halnya dengan merek Adidas yang juga mendukung gerakan untuk berdiam diri dirumah sebagai upaya untuk pencegahan penularan virus pada bulan Maret 2020 meluncurkan kampanye melalui tagar \#hometeam sebuah komunitas daring yang terdiri dari para atlet yang membagikan tips latihan dan berolahraga di rumah agar pikiran dan tubuh tetap aktif juga tertantang. Kampanye ini dikomunikasikan melalui akun sosial media

\section{Nike's revenue worldwide from 2005 to 2020}

\section{(in million U.S. dollars)}

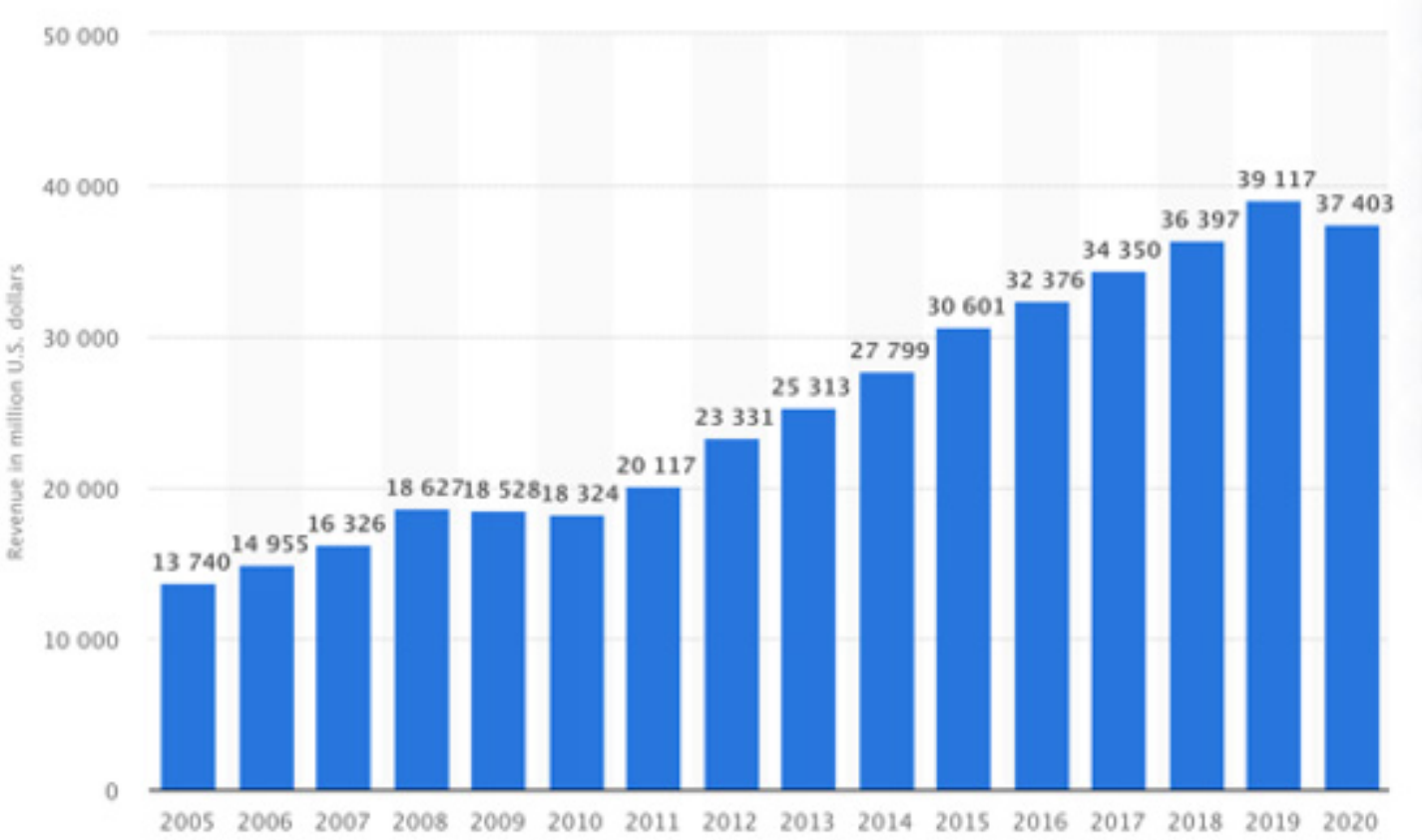

Sumber: Statista.com, 2020

\section{Gambar 3 Data pendapatan Nike secara global}




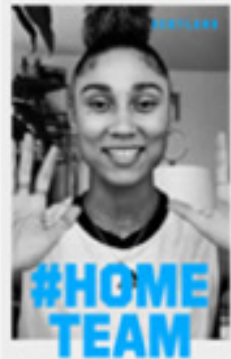
atr tave

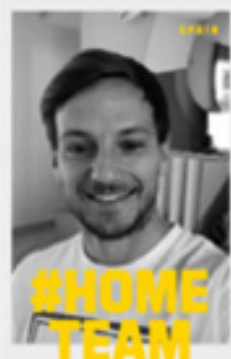

iva intitit

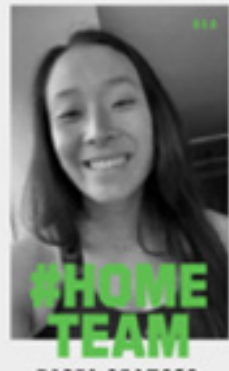

ตละ oxamots

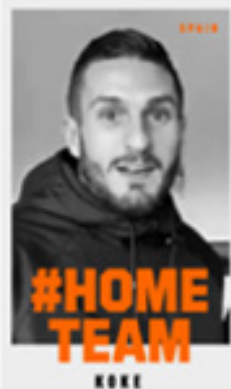

c11

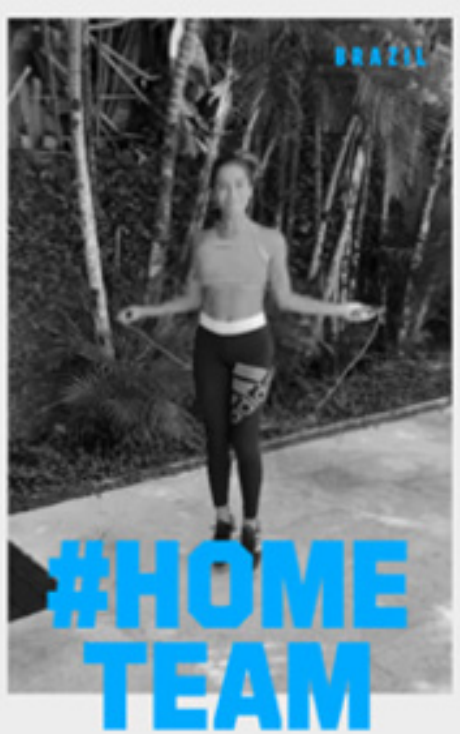

A MIT TA

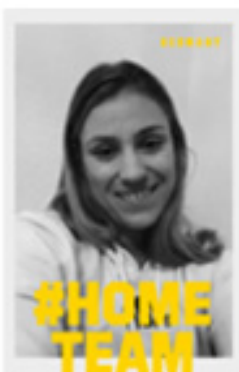

astuat xtata

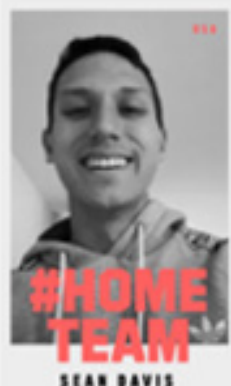

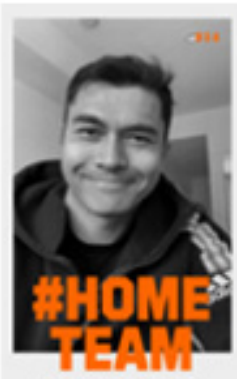

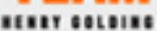

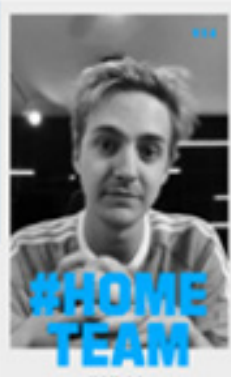

18

Sumber: nielsensports.com, 2020

\section{Gambar 4 Kampanye \#hometeam Adidas}

resmi merek Adidas serta akun media sosial milik pengikut akun merek Adidas.

Perubahan perilaku konsumen terjadi akibat dari penyesuaian terhadap regulasi yang berlaku di masa pandemi. Sebagai contoh dengan adanya pembatasan sosial berskala besar menyebabkan konsumen lebih banyak melakukan berbagai aktivitas didalam rumah mulai dari bekerja, bersekolah, berolahraga sampai dengan berbelanja dan mencari informasi mengenai produk dilakukan melalui pemanfaatan teknologi komunikasi dan informasi. Diperkirakan pasca pandemi pun, pemasar atau merek akan menjalankan strategi pemasaran digital yang menjadi sebuah kenormalan baru bagi merek. Menurut Kotler dalam artikelnya yang berjudul "The Consumer in the Age of Coronavirus" menyatakan bahwa konsumen akan lebih menghargai nilainilai kekeluargaan dan persahabatan, akan menggunakan media sosial untuk memberikan advokasi terkait konsumsi produk pangan dan sandang serta merek mana yang sekiranya dapat memiliki tujuan besar untuk mengakomodir semua kebutuhan tersebut (Kotler, 2020).

Kemunculan sosial media merepresentasikan perubahan paradigma dalam komunikasi merek (Jenkins, 2006). Melalui pemanfaatan media sosial sebagai media kampanye produk, perusahaan berusaha mengkomunikasikan secara ekspilisit ciri khas dan karakteristik apa yang ditawarkan kepada konsumen. Perusahaan secara kreatif dan informatif menyampaikan pesan yang perlu 
disampaikan kepada konsumen agar persepsi konsumen seusai dengan apa yang diharapkan oleh perusahaan (Bititci, et al., 2004). Perusahaan dapat memanfaatkan media sosial untuk melakukan kegiatan komunikasi merek.

Sifat dari sosial media itu sendiri merupakan kanal yang digunakan untuk berbagi konten yang dibuat pengguna seperti halnya kampanye \#hometeam Adidas, dimana Adidas melibatkan konsumen untuk turut serta menggunakan tagar tersebut dalam postingannya. Hasilnya terdapat lebih dari 400 ribu pengguna akun Instagram menggunakantagartersebut. Selainmembagikan konten yang dapat mempercepat penyebaran informasi juga pada konektivitas dan jaringan serta pada keleluasaan penggunanya dalam berkomunikasi, membuat konten kemudian membagikannya dan memberikan reaksi suka terhadap konten akun lain. Kesuksesan dari pemasaran melalui sosial media bukan hanya pada jumlah pengikut namun juga pada tingkat keterikatan yang muncul antara merek dan pengikutnya pada kanal tersebut (Smith, A.N., et al, 2012). Menurut hasil penelitian, postingan interaktif lebih banyak mendapatkan respon dibandingkan dengan konten informatif (Kusumasondjadja, 2018). Sosial media Instagram dinilai lebih cocok digunakan untuk konten interaktif yang dikombinasikan dengan konten informatif dan menghibur.

Konten dari merek Adidas memiliki tingkat interaksi yang lebih tinggi bila dibandingkan dengan konten dari merek Nike yang hanya menghasilkan lebih dari 60 ribu postingan bertagar \#playinside yang menjadi isi pesan dalam komunikasi merek. Hasil dari studi empiris menunjukan bahwa konten yang dihasilkan oleh pengguna akun sosial media memiliki pengaruh positif pada merek dan keinginan membeli produk (Carah, N. \& Shaul, 2015). Studi pada efektifitas komunikasi pada sosial media telah menemukan bahwa konsumen cenderung mengikuti akun sosial media dari sebuah merek karena beberapa motif diantaranya untuk memenuhi motif utilitiarian dan simbolik, seperti untuk tetap update mengenai aktivitas promosi, untuk mendapatkan informasi mengenai produk baru dan mempunyai kesempatan untuk mempublikasikan dukungan pada merek (Jenkins, 2006).

Respon dari netizen merupakan hal yang penting bagi pemasar karena menandakan bahwa pesan yang disampaikan tersebut dapat diterima oleh pasar sasaran. Pemasar akan mendapatkan keuntungan ketika pengguna berkeinginan untuk meneruskan pesan merek pada temantemannya dan pengikutnya dengan cara membagikan informasi di timeline, menandai temannya pada kolom komentar agar temannya dapat membaca pesan merek tersebut, karena postingan yang diteruskan di sosial media 
dianggap sebagai pesan elektronik dari mulut ke mulut (e-WOM) (Lee, Mira., Youn, 2009). Oleh karena itu menciptakan konten merek pada sosial media yang dapat mengembangkan respon penuh arti dari konsumen merupakan hal yang paling penting dalam perencanaan strategi pemasaran melalui sosial media.

Pemilihan sosial media sebagai media komunikasi yang digunakan oleh merek Nike dan Adidas dalam menyampaikan pesan mereknya berhasil mempertahankan hubungan dengan konsumen yang dapat dilihat dari banyaknya respon yang dihasilkan setelah postingan mengenai anjuran berdiam diri di rumah sebagai dukungan terhadap upaya pencegahan virus Covid-19 dilakukan. Pesan yang disampaikan bukan lagi pesan penjualan melainkan imbauan dan yang bermuatan dukungan kepada komunitas mereknya untuk mematuhi anjuran dalam mencegah penularan virus Covid-19. Pesan yang disampaikan bukan hanya relevan dengan kondisi saat ini namun juga memperlihatkan upaya merek untuk berada pada posisi yang sama dengan konsumen, memberikan dukungan yang penuh pada halhal yang menjadi perhatian utama konsumen. Hal tersebut yang merupakan implementasi dari komunikasi merek berbasis empati dimana merek mencoba memahami apa yang menjadi perhatian utama dalam hal ini kekhawatiran terhadap penularan virus sehingga pemberian dukungan pada upaya pencegahan penularan merupakan pesan yang tepat untuk disampaikan pada kondisi pandemi Covid-19 seperti saat ini.

Penerapan pemasaran empati lainnya yang juga dilakukan oleh merek retail terbesar dari Jepang yaitu Uniqlo melalui akun media sosial dan website resminya. Merek Uniqlo lebih banyak membagikan pesan mengenai donasi yang dilakukan oleh perusahaan tersebut dalam website resminya. Dalam websitenya tersebut, Uniqlo menyampaikan pesan merek sebagai merek yang bukan hanya memberikan dukungan upaya pencegahan penyebaran virus Covid-19 melalui pesan kampanye merek namun lebih jauh lagi melalui tindakan nyata yaitu pemberian donasi pada hampir seluruh negara di dunia yang terdampak virus Covid-19. Nada dari suara pesan menjadi lebih manusiawi, bersifat sosial dan informatif. Pesan yang demikian menjadikan merek mempunya nilai lebih baik dimata konsumen sehingga menimbulkan brand trust dan meningkatkan level of engagement (Dias, Patricia, 2020).

Dalam halaman websitenya Uniqlo menyampaikan komunikasi merek "Inisiatif Uniqlo untuk Membantu Memerangi Covid-19". UNIQLO menyampaikan simpati yang tulus kepada mereka yang telah kehilangan orang yang dicintainya karena COVID-19 atau yang menderita virus tersebut. Untuk membantu menjaga kesehatan dan lingkungan pelanggan, mitra produksi, karyawan, dan komunitas kami, kami berupaya untuk menghadapi krisis yang belum pernah terjadi sebelumnya ini, dan 


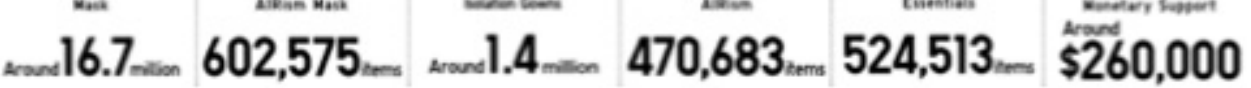

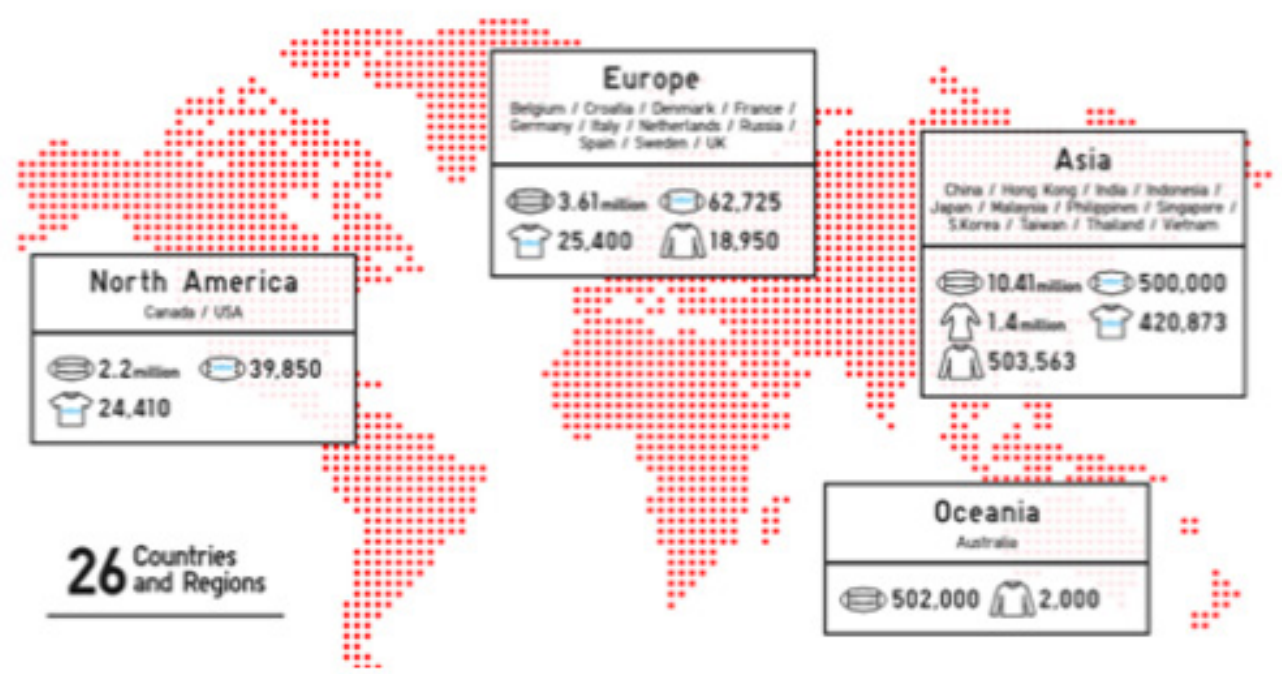

Sumber: Uniqlo.com, 2020

\section{Gambar 5 Informasi donasi Uniqlo saat pandemi}

untuk berkontribusi kepada komunitas global melalui sejumlah inisiatif.

UNIQLO memberikan dukungan kepada banyak orang berbeda di seluruh dunia yang terkena dampak COVID-19, terlepas dari apakah kami mengoperasikan toko di lokasi ini. Setelah menyumbangkan lebih dari 15 juta masker ke fasilitas medis di Jepang dan luar negeri dengan kerja sama mitra produksi kami, kami sekarang bekerja untuk membantu masyarakat melalui pakaian termasuk AIRism, HEATTECH, serta pakaian pelindung. Kami juga mulai menyumbangkan masker ke organisasi yang berafiliasi dengan duta merek global UNIQLO, dan kemudian memperluas donasi masker ke organisasi olahraga dan grup terkait olahraga di seluruh dunia, termasuk mitra global resmi kami, Komite Olimpiade dan Paralimpiade Swedia (Uniqlo.com, 2020).

Pesan yang disampaikan pada halaman website Uniqlo bukan hanya menyuarakan dukungan namun juga menunjukkannya dengan tindakan nyata yakni memastikan bahwa apa yang dilakukan lebih dari sekedar memberikan dukungan pada upaya pencegahan. Hal ini merupakan implementasi dari komunikasi merek berbasis empati dimana merek mencoba membantu dan meringankan beban yang dialami oleh khalayak. Pada level ini, merek Uniqlo berhasil meraih kepercayaan dan membangun keterikatan dengan konsumennya. Konsumen Uniqlo merasa bahwa dengan membeli produk Uniqlo berarti juga turut serta dalam memberikan donasi mulai dari masker, pakaian pelindung dan produk Uniqlo lainnya ke berbagai negara di dunia. Membangun keterikatan dengan cara melibatkan konsumen 
akan meningkatkan hubungan pelanggan yang lebih baik. Hubungan yang dibangun bukan lagi sekedar transaksional namun kolaboratif. Kolaborasi yang terjalin antara merek dan konsumennya dalam hal kondisi krisis seperti saat ini sangat diperlukan sehingga konsumen merasa menjadi bagian dari merek tersebut.
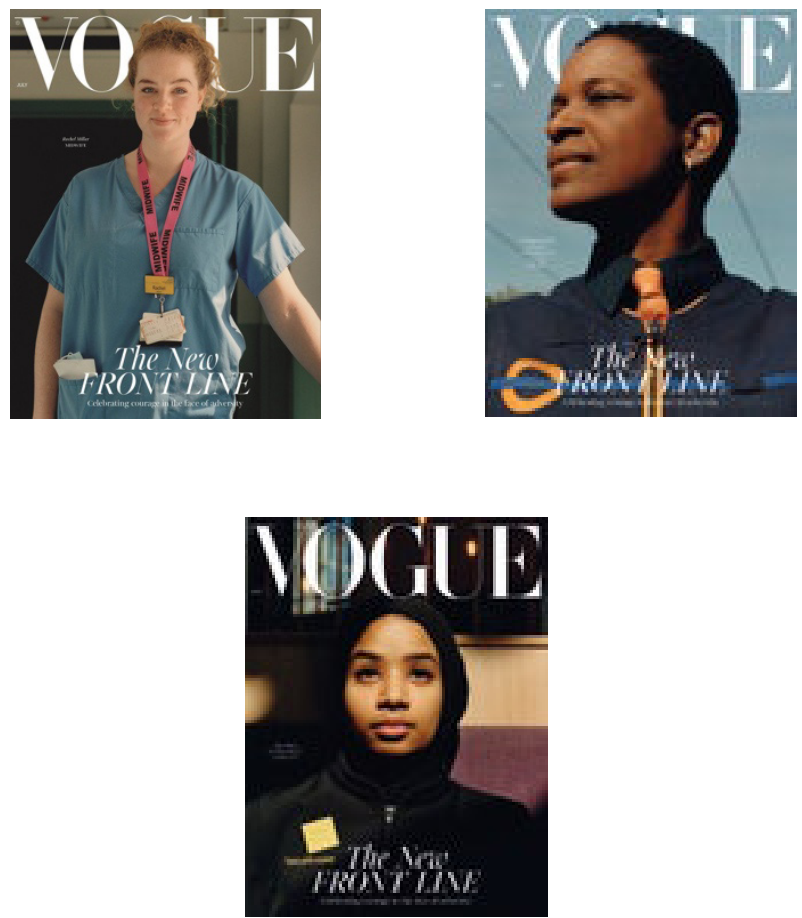

Sumber: vogue.co.uk, 2020

\section{Gambar 6 Cover Majalah Vogue di Masa Pandemi}

Lain halnya dengan komunikasi merek yang dilakukan oleh majalah fesyen terkenal Vogue yang selama ini memiliki citra sebagai majalah luxury fashion dengan menampilkan model, artis, public figure yang mengenakan riasan dari make up artist terkenal serta mengenakan busana rancangan designer kelas dunia pada cover majalahanya. Namun ada yang berbeda pada edisi Vogue di kala pandemi Covid-19.
Melalui tagline "The New FRONTLINE", majalah Vogue negara Inggris ini menampilkan tiga orang wanita yaitu Narguis Horsford yang bekerja sebagai masinis kereta London Overground, Rachel Millar yang berprofesi sebagai Bidan di wilayah London Timut dan Anisa Omar seorang pekerja di supermarket di King's Cross (Eninful, 2020).

Pada edisi sebelumnya, Majalah Vogue hanya menampilkan model yang mengenakan masker pada cover majalahnya. Namun pada edisi yang terbit pada saat awal pekan berlakunya aturan lockdown ini menampilkan pesan yang lebih mendalam. Pada edisinya tersebut, redaksi Majalah Vogue melalui tulisan Edward Enninful di website Vogue.co.uk menyebutnya dengan "a moment of thanks". Tim redaksi menyatakan bahwa ketiga wanita tersebut merupakan pilihan yang tepat untuk mewakili jutaan orang di Inggris yang pada puncak pandemi tetap mengenakan seragam dan pergi bekerja untuk membantu orang lain. Selama lebih dari sepuluh hari fotografer majalah Vogue Jamie Hawkesworth, berbekal senjata kamera, sepeda dan masker berkeliling kota pada jarak yang aman untuk menangkap gambar wajah para pemberani yang berkomitmen untuk membantu sesamanya.

Apa yang dilakukan oleh Majalah sekelas Vogue tentunya merupakan langkah yang besar dengan menampilkan sesuatu yang berbeda 
namun tetap relevan dan pesan yang mendalam. Dan hal tersebut berhasil dikomunikasikan dengan baik pada narasi dan tampilan cover majalahnya. Penyampaian pesan yang positif, jujur didukung tampilan visual yang sangat apik sekelas Majalah Vogue merupakan langkah yang seharusnya diikuti oleh pemasar produk luxury lainnya. Pesan yang disampaikan bukan lagi menampilkan high end fashion yang sedang trend yang tentunya menjadi kontradiktif dan tidak relevan dengan kondisi krisis akibat pandemi Covid-19 dimana fashion bagi sebagian besar bukan lagi menjadi perhatian utama dan penting.

Berdasarkan hasil temuan dan pemaparan yang disampaikan, dapat digambarkan model komunikasi merek berbasis empati pada gambar 7. Pada tingkatan awal pemasaran empati melalui komunikasi yang dilakukan oleh merek yaitu hanya berfokus pada pemberian dukungan atau endorsement melalui peningkatan kesadaran terhadap upaya pencegahan penyebaran virus Covid-19 melalui penyampaian pesan anjuran untuk berdiam diri di rumah, menjaga jarak dan mengenakan masker seperti yang dilakukan oleh banyak merek. Media yang banyak digunakan yaitu sosial media dengan memanfaatkan hampir semua fitur dengan mengunggah postingan foto dan video untuk tetap menjaga hubungan baik dengan konsumen melalui pesan interaktif berupa ajakan-ajakan serta penggunaan hashtag oleh para pengikut akun sosial media merek tersebut yang dapat dijadikan ukuran pesan tersebut diterima dengan baik oleh khalayak.

Pada tingkatan selanjutnya pesan merek yang disampaikan bukan hanya dukungan berupa tagline ataupun hastag namun melalui tindakan nyata atau ensure yaitu memastikan bahwa merek tersebut melakukan hal yang lebih nyata dengan cara melakukan donasi yang tentunya didukung oleh narasi yang kuat serta informatif sebagai bentuk dukungan atau endorsement. Pesan merek disampaikan melalui website resmi perusahaan sehingga menunjukan kredibilitas penyampai pesan merek. Pada tingkatan ini, bukan hanya pada bagaimana merek tersebut menyampaikan janji merek namun lebih jauh dari itu untuk memberikan tujuan yang lebih besar seperti pemberian donasi yang membutuhkan upaya dan komitmen yang sangat besar dari perusahaan. Terlebih di masa krisis dimana tentunya

\section{Endorsement}


pendapatan perusahaan menurun namun masih tetap berupaya memberikan yang terbaik bagi bukan hanya kepada konsumennya namun juga kepada khalayak luas. Pendistribusian donasi bukan hanya ke negara dimana merek tersebut beroperasi namun juga ke wilayah terdampak yang tidak terdapat lokasi penjualan produk.

Tingkatan yang paling penting dalam pemasaran empatiadalah membangun hubungan emosional yang kuat sebagai upaya merek dalam menjangkau konsumen dan membuat konsumen merasa terhubung melalui pemberian penghargaan sebagai bentuk empowerment atau pemberdayaan kepada khalayak. Merek yang memiliki ikatan emosional terkuat dengan konsumennya adalah merek yang memiliki rasa penghargaan. Inilah merek yang dapat menjadi teman, sumber inspirasi, yang dapat membantu konsumen dalam menciptakan dan memelihara ikatan sosial. Dalam situasi krisis seperti saat ini, menjadi hal yang lebih penting. Penyampaian pesan berupa realitas sosial yang berubah dengan membagikan momen yang membuat saling terhubung, membantu hubungan sosial selama isolasi ataupun menyebarkan perasaan penghargaan, kebahagiaan dan kasih sayang merupakan bentuk pemberdayaan melalui hubungan emosiaonal merupakan tingkatan komunikasi merek lebih lanjut yang dapat dilakukan oleh pemasar. Majalah fashion ternama Vogue merupakan salah satu merek yang berhasil mengimplementasikan pemasaran empati melalui penyampaian pesan komunikasi merek yang bukan hanya relevan namun juga mendalam dan menyentuh secara emosional. Penghargaan yang diberikan Vogue pada orangorang yang umumnya tidak dipandang sebagai orang yang berjasa dalam membantu orang lain melewati masa pandemi menjadi sesuatu yang sangat bernilai emosional tinggi di situasi krisis pandemi Covid-19.

\section{SIMPULAN}

Era pandemi Covid-19 mengubah banyak aspek kehidupan secara cepat termasuk pada bagaimana perusahaan harus beradaptasi pada perubahan perilaku konsumen. Kegiatan pemasaran dalam hal bagaimana perusahaan berkomunikasi dengan pelanggan memerlukan penyesuaian dengan kondisi saat ini dimana hampir seluruh dunia mengalami resesi dan menyebabkan daya beli menurun. Pada saat krisis, konsumen menjadi sangat sensitif dan tanggap terhadap komunikasi merek. Konsumen cenderung melihat dengan seksama pada merek yang tetap menjaga relevansi dengan kondisi yang terjadi dan bisa jadi menjadi pertimbangan utama dalam pemilihan konsumsi merek.

Covid-19 membentuk kembali cara merek terlibat dengan konsumen. Bila ingin membangun ketahanan merek selama krisis ini, merupakan saat yang tepat untuk 
mengubah strategi komunikasi merek dengan mempertimbangkan pentingnya melibatkan konsumen. Berdasarkan temuan, tema berulang yang dilakukan oleh merek global saat ini adalah dengan menyampaikan kepedulian merek berupa dukungan untuk ikut terlibat dalam upaya pencegahan melalui penyampaian pesan-pesan pencegahan penularan maupun tindakan kemanusiaan dengan cara melakukan donasi, mengenai bagaimana berosialiasasi dengan cara baru, berkegiatan dengan cara baru serta mendukung segala tindakan yang mengarah pada hal-hal yang dapat berkontribusi pada menurunnya jumlah penyebaran virus Covid-19.

Kampanye yang diluncurkan bertema upaya pencegahan penyebaran virus seperti menjaga jarak, berdiam diri di rumah, mengenakan masker ketika bepergian dan kegiatan donasi perusahaan yang melibatkan konsumen serta apresiasi kepada orang-orang yang menjadi garda terdepan dalam menghadapi penyebaran virus Covid-19 sangat relevan dengan kondisi saat ini telah menjadi contoh bagi banyak pemasar dalam melakukan komunikasi dengan konsumennya.

Sebagai contoh bagaimana Nike menafsirkan kembali upaya pencegahan tersebut dalam kampanye melalui kanal media sosialnya dengan seruan untuk berdiam diri di rumah sebagai kesempatan besar untuk menjadi pemain dunia seperti yang selama ini diimpikan, merupakan langkah yang besar dalam memposisikan merek sebagai merek yang tetap relevan dalam kondisi apapun. Begitupun dengan merek lainnya, yang juga banyak mengkomunikasikan dukungan pada upaya pencegahan penyebaran virus Covid-19. Kondisi seperti ini dapat menjadi stimulus bagi para peneliti untuk menginvestigasi perubahan pada perilaku konsumen mulai dari proses identifikasi kebutuhan, pencarian informasi, keputusan pembelian sampai pada bagaimana perilaku konsumen pada saat produk tersebut sudah tidak dipergunakan lagi.

Sebagai saran bagi para pemasar, era pandemi dapat menjadi peluang untuk mendemonstrasikan nilai-nilai yang ada pada perusahaan yang juga ikut terdampak serta bagaimana mereka dapat bertahan dan menjaga hubungan dengan konsumen dengan tetap melakukan komunikasi merek yang relevan dan menerapkan empati didalamnya. Sementara bagi para peneliti bidang pemasaran ada pada kajian mengenai bagaimana efek sementara maupun permanen dari Covid-19 pada perilaku konsumen dan bagaimana strategi pemasaran dan kebijakan pemasaran dapat diadaptasi oleh perusahaaan.

\section{DAFTAR PUSTAKA}

Aaker, A. D. (2012). Building Strong Brands. 
New York: The Free Press.

Aaker, A. D. (2014). Aaker on Branding: 20 Principles That Drive Success. New York: Morgan James Publishing.

Anand, B. (2020). Brands must show compassion \& a sense of sacrifice in communication during pandemic. Retrieved from media4grotwh.com website: https://www.media4growth.com/ ooh-news/brands-must-show-compassiona-sense-of-sacrifice-in-communicationduring-pandemic-4824

Bititci,U.S., Martinez, V.,Albores, P. and Parung, J. (2004). Creating and managing value in collaborative networks. International Journal of Physical Distribution \& Logistics Management, Vol. 34 No(3/4), 251-268. Retrieved from https://doi. org/10.1108/09600030410533574

Cameron, C. D., Hutcherson, C. A., Ferguson, A. M., Scheffer, J. A., Hadjiandreou, E., \& Inzlicht, M. (2019). Empathy Is Hard Work: People Choose to Avoid Empathy Because of Its Cognitive Costs. Journal of Experimental Psychology: General, Online Fir(1), 1-15. Retrieved from http://dx.doi. org/10.1037/xge0000595

Carah, N. \& Shaul, M. (2015). Brands and Instagram: Point, tap, swipe, glance. Mobile Media \& Communication, 4(1), 69-84.

Coppola, G. (2017). What is an Empathy Map, and why is it valuable for your business? Retrieved from medium.com website: https://medium.com/swlh/what-is-anempathy-map-and-why-is-it-valuable-foryour-business-14236be4fdf4

Cuff, B., Brown, S. J., Taylor, L., \& Howat, D. (2012). Empathy: A review of the concept. Emotion Review, Publish On. Retrieved from http://emr.sagepub.com/content/ early/2014/12/01/1754073914558466
Dias, Patricia, et al. (2020). Brand Communication on Instagram during the COVID-19 Pandemic: Perceptions of users and brands. Participatory Communication Research Section (PCR).

Eninful, E. (2020). The July Issue Is Dedicated To The New Front Line. Retrieved from Vogue.co.uk website: https://www.vogue. co.uk/news/article/editors-letter-newfrontline-july-2020

Gary, D., R. Chun, R. V. Da Silva, and R. S. (2001). The Personification Metaphor as a Measurement Approach for Corporate Reputation. Corporate Reputation Review, 4(2), 113-127.

Hoekstra, J. C. P. S. H. L. (2020). Marketing in the Era of Covid-19. Italian Journal of Marketing, 20(1), 249-260. Retrieved from https://doi.org/10.1007/s43039-02000016-3\%0A

Ingenhoff, D., T. F. (2010). Positioning and Differentiation by Using Brand Personality Attributes. Corporate Communications: An International Journal, 15(1), 83101. Retrieved from doi:10.1108/ \%0D\%0A13563281011016859.\%0D\%0A

Jenkins, H. (2006). Fans, Bloggers, and Gamers: Exploring Participatory Culture. New York: New York University Press.: New York University Press.

Keller, K. L. (2013). Strategic Brand Management (Global Edi). London: Pearson Education International.

Kotler, P. (2020). The Consumer in the Age of Coronavirus. Retrieved from The Marketing Journal website: https://www. marketingjournal.org/the-consumer-in-theage-of-coronavirus-philip-kotler/

Kotler, P. \&, \& Garry Armstrong. (2005). Marketing An Introduction (7e ed). New Jersey: Pearson Education International. 
Kotler, P. \&, \& Keller. (2012). A Framework for Marketing Management (Internatio). Edinburgh: Pearson Education International.

Kusumasondjadja, S. (2018). The Roles of Message Appeals and Orientation on Social Media Brand Communication Effectiveness: An Evidence from Indonesia. Asia Pacific Journal of Marketing and Logistics, 30(4), 1135-1158.

Lee, Mira., Youn, S. (2009). Electronic word of mouth (eWOM) How eWOM platforms influence consumer product judgement. International Journal of Advertising, 28(3), 473-499. Retrieved from https://doi. org/10.2501/S0265048709200709

Miao, Y. (2021). Brand Communication of Intangible Elements Delivery. Journal of Marketing Communications, 7(3). Retrieved from https://doi.org/10.1080/13 527266.2019 .1674363

Moleong, L. J. (2017). Metode Penelitian Kualitatif. Bandung: Remaja Rosdakarya.

Murdough, C. (2009). Social Media Measurement It's Not Impossible. Journal of Interactive Advertising, 10(1), 94-99.

Putri, N. E., Hakim, N., \& Yamin, M. (2016). Ecologicall Footprint and Biocapacity Analysis for Flooding Prevention in South Sumatera. Jurnal Mimbar, 32(1), 58-64.

Rahmawan, D; Mahameruaji, J. N. J.P.A.(2020). Strategi aktivisme digital di Indonesia: aksesibilitas, visibilitas, popularitas dan ekosistem aktivisme. Jurnal Manajemen Komunikasi, 4(2), 123-144.

Santoso, R. (2020). Review of Digital Marketing
\& Business Sustainability of E-Commerce During Pandemic Covid19 In Indonesia. Jurnal Ilmu Ekonomi Terapan, 5(2), 3648. Retrieved from https://e-journal.unair. ac.id/JIET

Smith, A.N., Fischer, E. and Yongjian, C. (2012). How does brand-related user-generated content differ across YouTube, Facebook, and Twitter? Journal of Interactive Marketing, 26(2), 102-113.

Social, W.A. (2021). Digital 2021 For Indonesia. Retrieved from https://datareportal.com/ reports/digital-2021-indonesia

Steimer, S. (2020). How Marketers Are Working During the Pandemic. Retrieved from American Marketing Association website: https://www.ama.org/marketingnews/how-marketers-are-working-duringthe-pandemic/

Sugiyono. (2016). Metode Penlitian, Kuntitatif, Kualitatif, dan R\&D. Bandung: Alfabeta.

Uniqlo.com. (2020). UNIQLO Initiatives to Help Combat COVID-19. Retrieved from https://www.uniqlo.com/en/sustainability/ covid-19response/index.html

Zed, M.(2004). Metode Penelitian Kepustakaan. Yogyakarta: Yayasan Obor Indonesia.

Zehir, Cemal, ., Azize Şahin., Hakan Kitapçı., Mehtap Özşahin. (2011). The Effects of Brand Communication and Service Quality In Building Brand Loyalty Through Brand Trust; The Empirical Research On Global Brands. Procedia - Social and Behavioral Sciences, 24, 1877-0428. Retrieved from https://doi.org/10.1016/j. sbspro.2011.09.142 